\title{
An Analogical Approach to Colors and Symbolism in Romanian and Turkish Folk Art
}

\author{
Rumen ve Türk Halk Sanatında Renklere ve Simgeciliğe Analojik Bir Yaklaşım
}

\section{Özlem Kaya* (), Sinziana Romanescu* ${ }^{*}$ (1)}

\begin{abstract}
Folk art is defined as creation that does not belong to the classical or modern arts but is generally included in traditional or domestic handcraft production. Works of folk art are generally of anonymous origin; their producers have not graduated from aesthetic or artistic studies in the narrowest sense.

The discovery of the phenomenon of folk art as a valuable part of culture is due to the development of the science of art history at the end of the $19^{\text {th }}$ century. From the aesthetic and historical point of view, it occurred in parallel with the gradual disappearance of this phenomenon in the European societies that were in the process of industrialization. At the end of the $19^{\text {th }}$ century, with the gradual disappearance of handicraft traditions in Central and Western Europe and later in Eastern Europe, folk art lost its original foundation. Due to theories of primitivism, popular art was given special attention during this period by - and thanks to -artists of the modernist trend.

During this period, folk clothes and clothing motifs were seen frequently. In particular, various pictures, colors, symbols, lines and images representing flowers were used quite often. What the grounds for all these people are, their importance, their depth, why they are repeated and how they are repetitive patterns are hidden in these clothes and works.

Preservation of the national culture and the local folklore is very important and we think, first and foremost, that we should understand the significance of these symbols and colors that represent our heritage.

The aim of this study is to analyze colors and symbols in Romanian and Turkish Folk Art with an analogical approach. In this study, examples of colors and symbols in Romanian and Turkish Folk Art were examined from areas such as clothing, weaving and ceramics and the use of symbols, the meanings of colors were conveyed and supported by patterns and it was concluded that there were similarities as well as regional differences between the two countries.
\end{abstract}

\section{Keywords}

Culture, Folk Art, Symbolism, Colors, Romanian and Turkish Folk Art

\section{Öz}

Halk sanatı, klasik veya modern sanatla ilişkili olmamakla birlikte genellikle geleneksel veya yerli el sanatları üretimi içerisine dahil edilen kreasyonu ifade etmektedir. Halk sanatı eserlerinin genellikle kökeni belirsizdir, bu eserlerin üreticileri en dar anlamıyla estetik veya sanat alanındaki eğitim programlarından mezun değildir. Halk sanatı olgusunun kültürün değerli bir

* Correspondence to: Özlem Kaya (Assist. Prof. Dr.), Hitit University, Faculty of Fine Arts, Design and Architecture, Department of Textile and Fashion Design, Çorum, Turkey. E-mail: ozlemkaya@hitit.edu.tr ORCID: 0000-0002-8572-6577

** Sinziana Romanescu (Assoc. Prof. Dr.), Ovidius University, Fine Arts Department, Constanta, Romania. E-mail: sinzianaromanescu@icloud.com ORCID: 0000-0002-3609-2192

To cite this article: Kaya, Ozlem \& Romanescu, Sinziana. "An Analogical Approach to Colors and Symbolism in Romanian and Turkish Folk Art." Art-Sanat, 15(2021): 161-181. https://doi.org/10.26650/artsanat.2021.15.0007 
parçası olduğunun keşfedilmesi 19. yüzyılın sonunda sanat tarihi biliminin gelişmesi ile gerçekleşmiştir. Estetik ve tarihsel açıdan bakıldığında, bu keşif sanayileşme sürecinden geçen Avrupa toplumlarında bu olgunun gittikçe ortadan kalkmasıyla bağlantılı olarak meydana gelmiştir. 19. yüzyılın sonunda Orta ve Batı Avrupa'da ve daha sonra Doğu Avrupa'da da el sanatı geleneklerinin giderek kaybolması ile birlikte halk sanatı asıl temelini yitirmiştir. İlkelcilik teorilerinden dolayı halk sanatına bu dönemde yenilikçi eğilimin sanatçıları tarafından - ve bu sanatçılar sayesinde - özel bir ilgi gösterilmiştir. Bu dönemde çalışmalarda halk giysileri ve giysi motifleri sıkça görülmüştür. Özellikle çiçekleri temsil eden çeşitli resimler, renkler, semboller, çizgiler ve görüntüler oldukça sık kullanılmıştır. Tüm bu halka dair temellendirmelerin ne olduğu, önemi, derinliği, neden tekrarlandığı ve tekrarlanma şablonunun nasıl olduğu da bu giysilerde ve eserlerde gizlidir.

Ulusal kültürün ve yerel folklorun korunması büyük önem arz etmektedir ve her şeyden önce mirası temsil eden bu simgelerin ve renklerin önemini anlamak gerekmektedir. Bu bağlamda bu çalışmanın amacı, Rumen ve Türk Halk Sanatındaki renk ve simgeleri analojik bir yaklaşımla ele almaktır. Çalışma ile Rumen ve Türk Halk Sanatındaki renkler ve simgeler giysi, dokuma, seramik gibi alanlardan örnekler verilerek simgelerin kullanımı ve renklerin anlamları aktarılmış, desenler ile desteklenmiş ve bu noktada iki ülke arasında bölgesel farklılıklar kadar benzerliklerin de olduğu sonucuna ulaşılmıştır.

Anahtar Kelimeler

Kültür, Halk sanatı, Simgecilik, Renkler, Romanya ve Türk halk sanatı

\section{Genisletilmis Özet}

Bir toplumun ortak zihni olarak ifade edilen kültür, kültürel simgeler ile aktarımını gerçekleştirmektedir. Kendine ait simgeler aracılı̆̆ıyla her kültür, farklı deneyimlerin ve algıların aktarılmasını ve yaratılmasını sağlamaktadır. Bu noktada kültürel simgeler, bireylere inanma, hissetme, düşünme vb. biçimlerini aktararak anlamlandırmanın temelini oluşturmaktadır. Bir diğer ifadeyle kültür, bir toplumun hem toplum içindeki bireyleri arasında hem de diğer toplumlar ile olan ilişkilerinde iletişim aracı rolünü üstlenmektedir.

Ulusal kültürel simgeler ulusların sanat anlayışlarını, tarihsel olaylarını, geleneklerini, inançlarını, gündelik yaşantılarını yansıtmaktadır. Aynı zamanda bireylerin yaşadıkları topluma aidiyet hissetmesine aracılık ederek kolektif duygunun yaratılmasına katkı sağlamaktadır. Kültürel simgelerin bir toplumun değerlerinin ve ortak anlamlarının aktarılmasında belirleyici ve kavramsallaştırıcı bir özelliği bulunmaktadır. Bu özellik, kendisine güç vermekte ve kavramsal bilginin parçalarının birleştirilmesinde insan hafızasında yer edinmesinde çok etkili olmaktadır. Kültürel simgelerin yokluğu durumunda bir kavramın yanlış anlaşılması ya da farklı şekillerde anlamlandırılması söz konusu olabilmekte, bu da kültürün sürekliliği ve gelecek nesillere aktarılması açısından bir tehdit oluşturmaktadır.

Tarihe bakıldığında, Osmanlıdan Selçukluya, Selçukludan Orta Asya Türk topluluklarının sanat yapıtları incelendiğinde dokumalar, seramikler, çiniler, el yazmaları, mimari yapılar vb. eserlerin geçmişten günümüze belli bir gelişme kaydederek, dönemlerinin en iyi örneklerini verdikleri görülmektedir. Bu tarihî süreçte Türk süsleme sanat1, göçebe toplum sanatından, günümüz yerleşik toplum sanatına kadar geçen sürede, sosyal sınıf farklılığının getirisi olarak halk ve saray sanatı olmak üzere iki gruba ayrılmıştır. 
Türk süsleme motifleri kendi anlamları içinde bir bütünlük sağlayarak karşımıza çıkmaktadır. Türk desen ve motiflerini araştırırken kaynaklar dönemden döneme, yaşam biçimlerine ve inanç sistemine göre değişikliklere uğramıştır. Türk toplumunun göçebelikten yerleşik hayata geçişi, İslam dinini kabul etmeleri, farklı toplumlarla iç içe yaşamaları, Türk motiflerinin çok yönlü gelişmesine sebep olmuştur. Ortak efsaneler, inanç sistemleri, coğrafya ve iklim koşulları içinde Türk desen ve motifleri binlerce yıllık bir gelişme, olgunlaşma süreci geçirmiştir. Desen ve motif açısından iç içe geçen bu sanatlarda uygulandıkları alanlara göre başarılı örnekler verilmiştir.

Daçyalıların antik dönemine kadar uzanan ortak bir kültürel mirası paylaşan Rumen halkı için ise ülkenin dört bir yanındaki saraylar, kaleler, kiliseler, manastırlar ve sinagoglar 12. yüzyıla kadar uzanan hareketli geçmişin mimari tanıklarıdır. Rumen halk sanatı da bugün çok popüler olan uzun bir geleneğe sahiptir. Boyalı yumurtalar, el sanatları, seramikler, ahşap işleri, cam işleri gibi alanlar bunun en canlı kanıtıdır. Bununla birlikte en yaygın geleneksel zanaat tekstildir. Dokuma ve nakış, katı kalıpları olan ve hatta yalnızca belirli bölgelerde insanlar tarafından bilinen bir tür gizli dil yaratmıştır. Bu bakımdan, Rumen kültürü içinde dönemsel olarak gelişim kaydedilmiş ve başarılı örnekler verilmiştir. Özellikle geleneksel halk giysileri, renkleri ve simgeleriyle ulusal mirasın hâlâ hayatta olan Rumen mitolojisinin ayrılmaz parçasıdır. Bu bağlamda geleneksel Rumen halk giysisi için aynı zamanda sanat ve tarihtir diyebiliriz.

Gerek Rumen gerek Türk kültüründe geleneksel ürünlerde kullanılan motiflerin neleri anlattıkları nelerden bahsettikleri her dönemde insanların ilgisini çekmiştir. Motiflerin kendisini üreten insanla nasıl bir birliktelik kurulduğu, insan-motif ilişkisinin gelişim süreci anlaşılmaya çalışılmıştır. Çünkü değişen, her dönemin insanı değil, her dönemin sanatıdır.

Türk süsleme desenlerinden hatayi, bulut, rumi, lale, çintemani, hayat ağacı gibi birçok motif ile oluşturulmuş eserlere bakıldığında dönemin halk giysilerindeki simgeler ve renklerin neler olduğu, kullanılan tekniklerin ve malzemelerin bilgisine ulaş1labilmektedir. Bu düşünceden yola çıkarak, çintemani, lale, yıldız, ağaç, kuş gibi motiflerinden yararlanarak bazı örnekler verilmiştir. Ağaç kültürü, halk sanatımızda halıda, kilimde, işlemelerde, çoraplarda olmak üzere birçok alanda kendini göstermektedir. Çintemani motifi, Osmanlı saray sanatında çok kullanılan bir motifken, aynı dönemin halk sanatlarında kendini hiç göstermemiştir. Lale motifi, Osmanlı saray sanatında altın dönemini yaşamış, halk sanatında da kendini kısmen ifade edebilmiştir. Yıldız motifi, Osmanlı saray sanatında olduğu gibi, halk sanatında da kendinden çok söz ettirmiştir. Kuş ve hayat ağacı motifleri ise Osmanlı saray ve halk sanatlarından çeşitli uygulamalarla günümüze kadar gelebilmişlerdir.

Çini örneklerine bakıldığında ise, yıldız formlar üzerine uygulanan yoğun figür kullanımı görülmektedir. Bu çinilerde Selçuklu dönemi çinilerinde görülen firuze, 
kobalt mavisi, mor ve siyahın yanı sıra yeşil, kahverengi, sarı, kırmızı ve altın yaldız kullanımı dikkat çekmektedir. Milet işi diye anılan şeffaf sır altına mavi tonlarında, firuze, mor, siyah, yeşil renklerle boyanan ve beyazımsı krem rengi astarla kaplanan kırmızı hamurlu çinilere 14. yüzyıl sonlarında rastlanmaktadır. Bunlar, Erken Osman11 döneminde en yaygın gruplardan birini oluşturan kırmızı hamurlu seramiklerdir. Bezemelerinde çiçek, yaprak, palmet, rumi, kıvrık dallardan oluşan bitkisel, yıldız, altıgen, rozet, helezon, dikey hatlı geometrik, balık, kuş gibi figürlü, dalga-kaya, inci dizisi gibi motifler kullanılmıştır.

Sanatsal geleneklerin bir parçası olan bu motifler, sosyal statü, sevgi, beklenti, inanç, evlilik, bekarlık, göç, afet, hüzün, neşe, mutluluk, özlem, ayrllık, dilek ve daha birçok olguyu ifade ve sembolize etmek için kullanılmıştır.

Rumen halk motiflerine bakıldığında ise daha çok gamalı haç, sekizgen, çember, daire, halat ve yılan gibi sembollerin kullanıldığı görülmektedir. Gamalı haç, güneşin sembolüdür. Aynı zamanda Romanya'nın etrafında dönen merkezi ve dünyayı temsil etmektedir. Yılan sembolü, Rumen kozmogonik efsanelerinde, dünyanın yaratılmasından önce dünyanın ağacında kıvrılmış görünmektedir. Bunun ise İmparator Yılan olduğuna inanılmaktadır. Daire sembolü ise çok eski bir dekoratif motiftir. Bugün bir güneş temsili olarak kabul edilmesine rağmen, güneş kültünün ortaya çıkmasından çok önce kullanılmıştır çünkü eski dinlerde daire kadın tanrıçaların temsilidir. Sekizgen ise kare ve daire arasında görünmektedir. Kare sınırlamadır ve daire sürekliliği ve sonsuzluğu temsil etmektedir. (Dünya (kare) ve gökyüzü (daire) arasında bir ara dünya).

Rumen ve Türk halk sanatında rengin ve simgeciliğin incelendiği bu araştırmada her iki ülkenin de farklı kullanımlarının kültürleriyle, gelenek-görenekleriyle ve bulundukları coğrafyayla ilgili olduğu, benzerliklerin ve farklılıkların bu bağlamda tüm alanlarda kendini gösterdiğini söylemek mümkündür. Bu kapsamda halk sanatında da tekstilden dokumaya ve giysiye, seramikten ahşaba birçok alanda özellikle söz konusu ülkelerin kültürlerine özgü simgelerin kullanıldığı ve renklerinde bu noktada farklı anlamlar içerdiği görülmüştür. Renkler, toplumların kültürlerinde eski çağlardan bu yana önemli bir simge olarak yer almıştır. Kimi zaman yönler tanımlanırken (Türklerde binlerce yıldır siyah rengin kuzeyin sembolü olarak kullanılması, kuzeydeki denizin Karadeniz olması gibi), kimi zaman milli duygular ifade edilirken, cinsiyet tanımlanırken, dinî kimlikler belirlenirken (Yahudiler için mavi rengin, Müslümanlar için ise yeşil rengin kutsal renk kabul edilmesi), camiler, kiliseler, tapınaklar ve mimari yapılar süslenirken vb. renkler simgesel anlamları düşünülerek kullanılmıştır. Günümüzde ise eski devirlerin renkteki simgeselliği yerini işlevselliğe bırakarak farklı bir boyut kazanmıştır. Artık bireylerin konforu, sağlığı ve verimliliği düşünülmektedir. Her kültürde renkler tarihin ilk dönemlerinden başlayarak farklı algılanmış ve yansı- 
tılmıştır. Ayrıca tarihî süreç içerisinde renklerin kültürlerde oldukça önemli simgesel anlamlar içerdiği ve bireylerin hayatlarına da yön verdiği görülmüştür.

Bu bağlamda Rumen ve Türk Halk Sanatındaki renk ve simgeleri analojik bir yaklaşımla sunmayı amaçlayan bu çalışmada giysi, dokuma, seramik gibi alanlardan örnekler verilerek renklerin ve simgelerin kullanımı aktarılmış ve bölgesel farklılıklar kadar benzerliklerde ortaya konmuştur. 


\section{Introduction}

National embroidery and folk costumes are not only a part of a long-standing tradition. In fact, they represent the entire cultural heritage of the Romanian peasant and the entire heritage of Romanian folk culture. Likewise, they represent the Turkish cultural heritage. This heritage is a holistic (unitary) whole of legends, stories, fairy tales, colors and meanings. It contains deep meanings and hidden symbolism. It tells a lot about the geographical area, history and tradition of each society in terms of preserving the original and tradition from prehistoric times.

These symbols were magical to our ancestors or carried luck. These symbols are used not only in clothing (shirts, pants) and ornaments (belt, scarf, handkerchief), but also on common household objects. The motifs vary greatly from flowers, leaves, and fruits to birds, animals, abstract figures and cosmic elements.

In folk art, colors are some of the meaningful parts of life and they played a very important role in a very long period of time from myths to contemporary poetry. The effect of colors on people has been known since ancient times. In various parts of daily life, human beings have sometimes used their desires, wishes and happiness, and sometimes their sorrows by reflecting them with colors. As is commonly known, colors have different meanings in each society. For example, as Gabain points out $(1968)^{1}$, white represents the west for Turks and the Chinese, while for Indians, white represents the east. It represents the south in the Old Testaments, and for the Mayans, it represents the north. The Hagia Sophia in Istanbul was built with red, green, blue and black colored marbles. The meanings that colors express in different cultures are different. Colors are some of the meaningful parts of life and vary according to cultures.

\section{Method}

The transfer of knowledge, culture and art, which has been created over thousands of years, to new generations, provides development and progress. One of the most functional ways for the individual to understand, make sense of and add new things to his/her past and present culture is to create awareness of the cultural values in the land he lives in. At this point, in this study, it is aimed to discuss the colors and symbols in Romanian and Turkish folk art with an analogical approach. In line with this purpose, in this study, the use of symbols, the meanings of colors were conveyed and supported by patterns, by giving examples from areas such as colors and symbols in Romanian and Turkish folk art, clothing, weaving and ceramics and it was revealed that there are similarities as well as regional-geographical differences between the two countries. In this study, the colors and symbols in Romanian and Turkish folk art were conveyed with an analogical approach and the importance of transferring them

1 Annemarie Von Gabain, "Renklerin Sembolik Anlamları," Türkoloji Dergisi 3 (1968), 107-113. 
to the next generations of the countries and continuing their cultures was revealed and some suggestions were made.

\section{Representation of Romanian Popular Symbols}

Each costume or area has a characteristic style. Costumes from Dobrogea to costumes from Oas, Oltenia or Apuseni. Each looks different, each one represents a world we have lost; an understanding that we can no longer "translate".

Today, we can only admire the beauty of these costumes and the enormous work that lies behind them. However, we can no longer perceive the message that was being given and we do not think about what these clothes mean. ${ }^{2}$ For this reason, we need to understand that every grandmother or young lady was trying to write her story, abandon her inheritance, take something from herself and leave it. It is a song of a long-gone world, when the sun rises only for heroes, virgins, good people and gifts. It is a world full of traps, seven-headed brooms, kites, hags, forest mums and other supernatural beings from popular Romanian mythology.

Folk costumes, their colors and symbols are an integral part of the national heritage, of a Romanian folk mythology that is still alive. ${ }^{3}$ The traditional Romanian folk costume is art and history at the same time. It is the story of the Romanian peasant from their origins to the present, from the harvesters, the hour of the village, where eternity was born. ${ }^{4}$

In the present, we consider these costumes as "traditional". However, they were a part of ordinary people. They were worn according to the area, season, specifics and activity. Costumes took into account the age or occupation of the woman and her social status. A rich egg (egg-like clothing, an important symbol for Romanian culture) is worn on holidays.

- Romania is divided into seven folkloric regions: ${ }^{5}$

- Transylvania

- Western plains

- Banat

2 Zlatin Zlatev, Liliana Indrie, Julieta Ilieva and Teodora Ivanova, "Analysis on Colors of Folk Costume and Their Application in Contemporary Textile Design," Annals of The University of Oradea Fascicle of Textiles, Leatherwork XX (2019), 125-130.

3 Liliana Doble, O. Stan, Marius Suteu, Adina Albu, G. Bohm, A. Tsatsarou-Michalaki, Eleni Gialinou, "Romanian Traditional Motif - Element of Modernity in Clothing," IOP Conf. Series: Materials Science and Engineering 254 (2017), 1-5.

4 Alexandra Mocenco, Sabina Olaru, Georgeta Popescu and Carmen Ghituleasa, "Romanian Folklore Motifs in Fashion Design," Annals of the University of Oradea Fascicle of Textiles, Leatherwork XV (2014), 63-68.

5 Jan Brunvand, "The Study of Romanian Folklore," Journal of the Folklore Institute 9 2/3 (1972), 133-161; Ion-Aurel Pop, Identitatea Românească (Romania: Contemporanul Publishing House, 2006), 14-26. 
- Valachia

- Lower Danube Area

- Moldavia

- Romanians from the Balkans: Aromanians, Meglenoromanians, Istroromanians, Daco-Romanians ${ }^{6}$

There are almost 120 ethnographic areas related to them. There are very isolated regions or communities that have developed their own identity within these large groups. ${ }^{7}$

- The most common Romanian folk motifs are: ${ }^{8}$

- Swastika $^{9}$

- Octagon

- Rope and snake

- The line

- The circle

The swastika is the symbol of the sun. She is not orientally-inspired. The swastika for the Romanian populous represents the center and the world that revolves around it - the Tree of the World, the cosmic tree, the center of the world - Axis Mundi. ${ }^{10}$

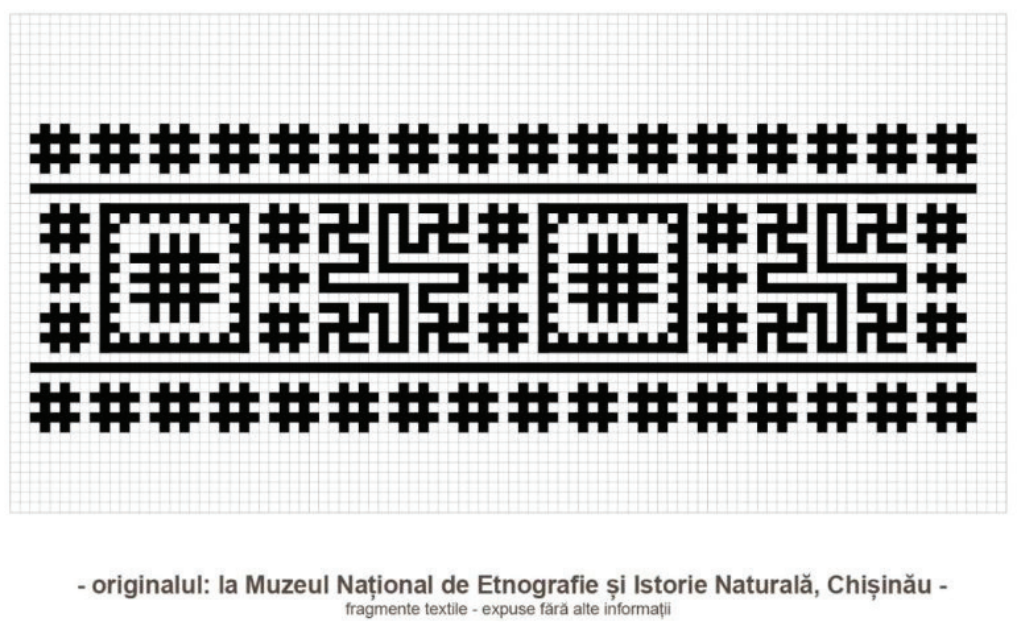

F. 1: Textile Fragments from Romanian Folklore. (Original Piece in National Ethnographic Museum, Chișinău, Republic of Moldavia. https://aleximreh.wordpress.com/2017/12/21/swastikain-old-europe/)

6 David Comas, H. Schmid, S. Braeuer, C. Flaiz, A. Busquets, F. Calafell, J. Bertranpetit, H-G. Scheil, W. Huckenbeck, L. Efremovska and H. Schmidt, "Alu Insertion Polymorphisms in the Balkans and the Origins of the Aromuns," Annals of Human Genetics 68-2 (2004), 120-127.

7 Ion Ghinoiu, Mica Enciclopedie De Tradiții Romaneşti (București: Agora Editura, 2008).

8 Martine Claessens, "Romania's Secret Language," accessed 19 December 2020, https://martineclaessens.com/

9 Roy R. Behrens, “The Swastika: Symbol Beyond Redemption (review)," Leonardo 34-3 (2001), 280.

10 Regina Coussens, "Folk Culture as Symbol in Contemporary Romania", Research Report 24: Economy, Society and Culture in Contemporary Romania 35 (1984), 129-138; Hannah Stoltenberg, "Sacred Movement: Connecting with the Divine Kathak as Axis Mundi," Journal of Dharma Studies 1 (2019), 303-312. 
The octagon appears between the square and the circle. The square is the limitation, and the circle represents the infinite, the continuity, the eternal; an intermediate world between earth (square) and sky (circle).
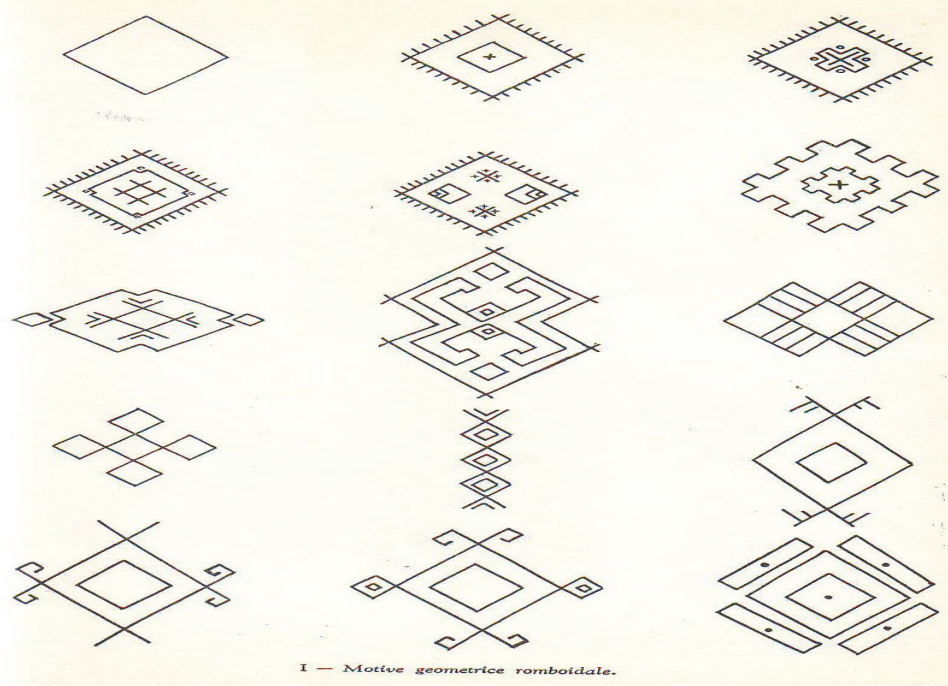

F. 2: Geometric Motifs from Romanian Folklore (https://unaltfeldejurnal.files.wordpress.com/2012/06/scan10017.jpg)

The snake appears to be related to Axis Mundi; he is with his fir tree or the Red Apple. In the Romanian cosmogonic legends, he appears before the creation of the world curled up on the Tree of the World. He is the Emperor Serpent.

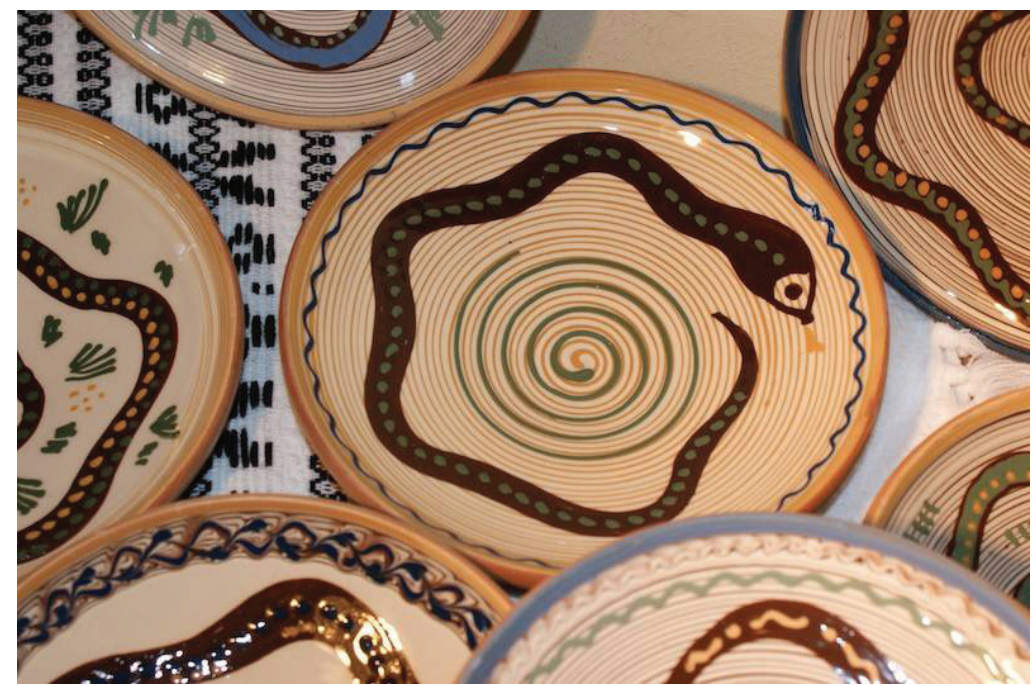

F. 3: The Snake Motif in Romanian Ceramic.

(https://www.artizanescu.ro/farfurie-romaneasca-traditionala---sarpele-casei-diam-17-5---18$\mathrm{cm} / 3772 . h \mathrm{tm} \#)$ 
In popular art, the line may be found throughout all historical eras to date. With the help of the line, anonymous artists have created a multitude of ornaments with special meanings. Regardless of whether it appears on ceramics, on wooden objects or on textile parts, the line is an unadorned ornament close to any object. With the help of two vertical lines on which the oblique lines are articulated, for example, a tree may be drawn.

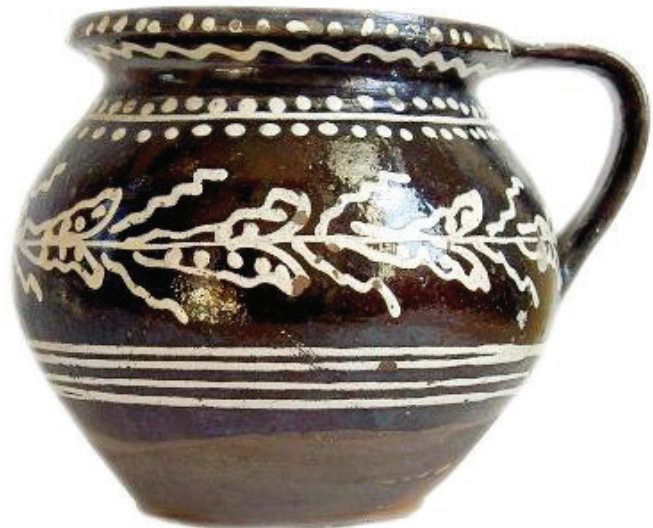

F. 4: The Line Motif in Romanian Ceramic. (https://limbaromana.org/revista/motive-geometrice/)

The circle is a very old decorative motif. Although, today, it is considered a solar representation, it was used long before the appearance of the solar cult because in older religions, the circle was the representation of female goddesses. After the emergence of the solar cult, it became a classic form of representation of the solar disk.

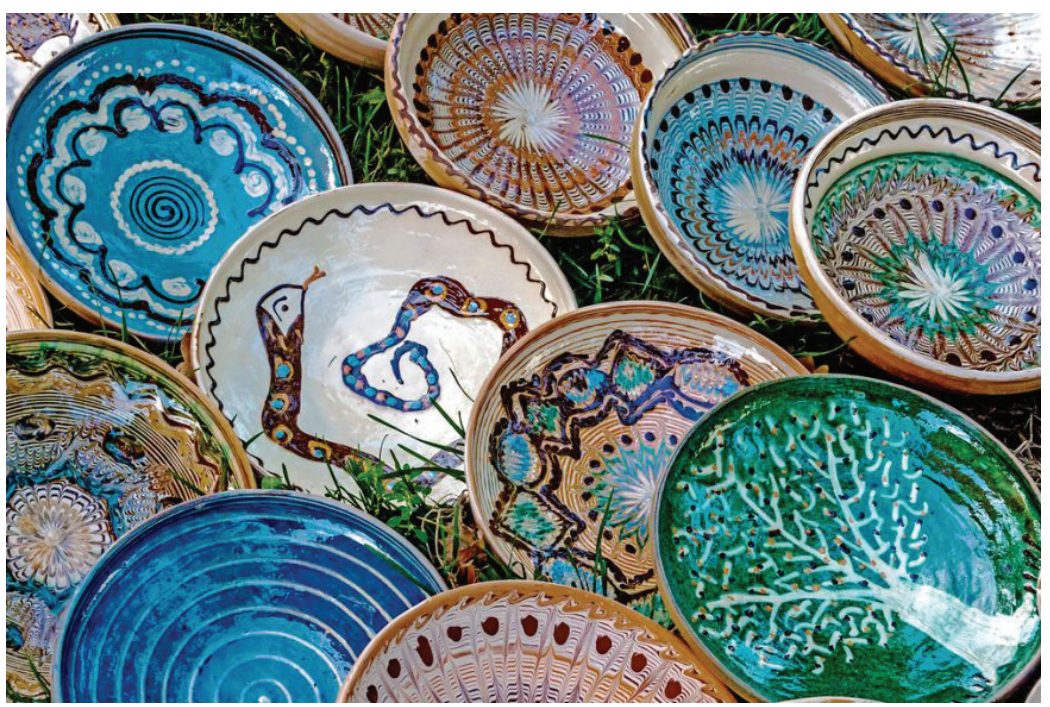

F. 5: The Circle Motif in Romanian Ceramic.

(https://www.invietraditia.ro/editorial/ceramica-autentica-romaneasca) 


\section{Representation of Turkish Popular Symbols}

The function of cultural symbols in creating a sense of social belonging is related to the way a community defines itself as a nation and conveys it by sharing common values and meanings. According to Smith (1991), the nation is a community of people who share historical lands, myths and legends, historical memories, culture, economy, legal rights and responsibilities. ${ }^{11}$ Sharing the same territory and being familiar with the same myths and legends make it valid to show social belonging to certain symbols. Smith emphasizes that national symbols are used in traditional clothes due to their particularly distinctive feature of national symbols, and that this should be considered as a national cultural symbol.

National cultural symbols reflect nations' daily lives, historical events, beliefs, traditions, and understanding of art. National symbols mediate individuals to feel they belong to the society in which they live and contribute to the creation of a collective emotion.

Cultural symbols have a decisive and conceptual feature in the transfer of values and common meanings of a society. This feature gives power to cultural symbols. Cultural symbols are very effective in uniting parts of conceptual knowledge in human memory. In the absence of cultural symbols, a concept may be misunderstood or interpreted in different ways, which poses a threat to the continuity of culture and its transmission to future generations. ${ }^{12}$

Cultural symbols are accepted as the power of culture in a sense. Culture has a decisive role in the formation of a common mental memory of a society and it can be accomplished through its cultural symbols. ${ }^{13}$ Therefore, cultural symbols are the power of culture. Cultural symbols, as well as providing the transfer of meaning, are also determinative in the formation of the mindset of individuals in the society and have a directing feature in the transfer of experiences. ${ }^{14}$

Looking at history, when the works of art from Ottoman to Seljuk, from Seljuk to Central Asian Turkish communities are examined, it can be seen that works such as weavings, ceramics, tiles, manuscripts, architectural structures, etc., have made a certain development from the past to the present and given the best examples of their periods. In this historical period, Turkish ornamental art was divided into two groups as folk and palace art, as the return of social class difference, from the nomadic society to the settled social art of today.

11 Michael E. Geisler, "Introduction: What Are the National Symbols and What Do They Do to Us?", National Symbols, Fractured Identities (Hanover and London: Middlebury College Press, 2005).

12 Omar Lizardo, "Cultural Symbols and Cultural Power,” Qualitative Sociology 39/2 (2016), 195-198.

13 Gözde Sazak, Türk Sembolleri Hun Dönemi Türk Motif ve Sembollerinin Sanata ve Hayata Yansıması (İstanbul: İlgi Kültür Sanat Yayınları, 2014), 145-148.

14 Clifford Geertz, The Interpretation of Culture (New York: Basic Books, 1973). 
Turkish ornamental motifs appear in our own meaning by providing integrity. While researching the Turkish patterns and motifs, the sources have changed from period to period, according to their lifestyle and belief system. The transition of the Turkish society from nomadism to settled life; their living together with different societies caused the multi-faceted development of Turkish motifs. From common myths to common belief systems, Turkish patterns and motifs have undergone thousands of years of development and maturation within the common geography and climate conditions. These arts, which are intertwined in terms of patterns and motifs, have given successful examples according to the fields in which they are applied to.

What these motifs tell us and what they talk about has always been of interest in every period. They try to reveal how a relationship was established with the human who produced them, and the developmental process of the human-motif relationship. Because it is not the person of every era that changes, but the art of every era.

When we look at the works created with many motifs among Turkish ornament patterns such as hatayi, cloud, rumi, tulip, çintemani, tree of life, information about the symbols and colors in the folk clothes of the period, the techniques and materials used can be accessed (F. 6).
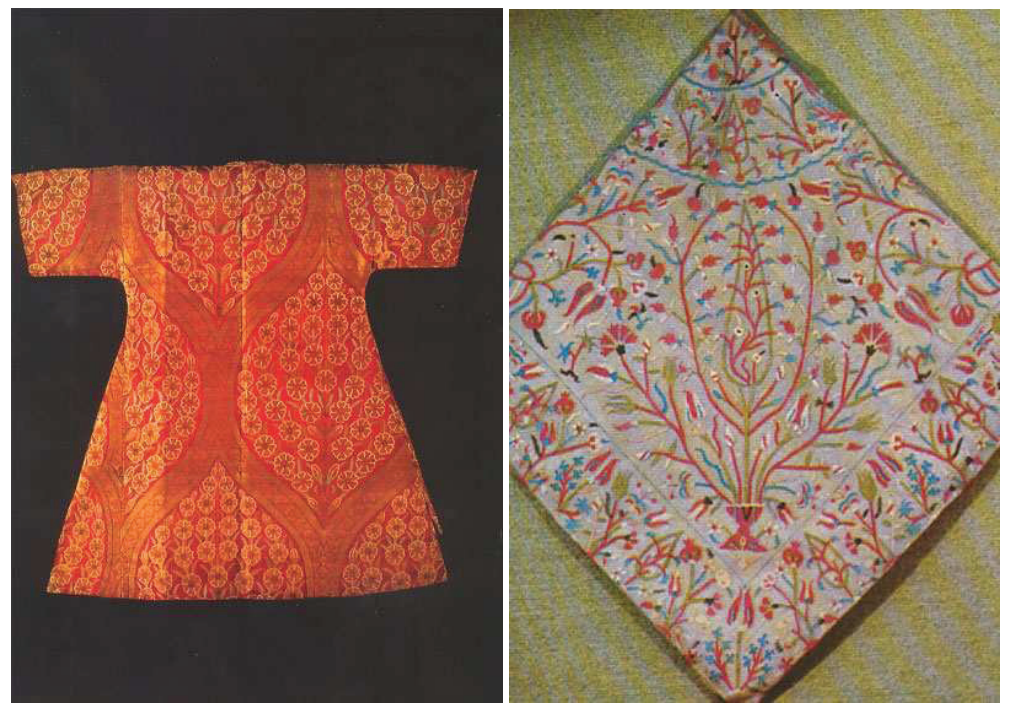

F. 6: $16^{\text {th }}$ Century Spring Branch Motifed Kaftan Belonging to II Beyazit. ${ }^{15}$

$17^{\text {th }}$ Century Palace Embroidered Kavuk Cover, Tulips, Cloves, Cypress Motifs Are Embroidered on Thin Cream Cotton-Silk Fabric ${ }^{16}$

15 Patricia Baker and Hülya Tezcan, Silks for The Sultans (İstanbul: Ertuğ \& Kocabıyık Yayınevi, 1998), 110, quoted in Ayşin Deniz Kuru, "Geleneksel Motiflerin Kimliklerini Kaybetmeden Yeni Tasarımlara Dönüşmeleri”, (M.A. Thesis, Mimar Sinan Fine Arts University, 2006), 23.

16 " $17^{\text {th }}$ Century Palace Embroidered Kavuk Cover, Cream Thin Cotton Silk Fabric on Tulips, Cloves, Cypress Motifs Are Embroidered," Sanat Dergisi 7 (Nisan 1982), 141 quoted in Ayşin Deniz Kuru, "Geleneksel Motiflerin Kimliklerini Kaybetmeden Yeni Tasarımlara Dönüşmeleri”, 24. 
Based on this idea, some examples are given by using motifs such as cintemani, tulips, stars, trees, and birds. The motif in Figure 6 is mostly named as spring branch or blooming branch. Tree culture shows itself in many areas in Turkish folk art, including carpets, rugs, embroidery and socks. While the cintemani motif is a motif widely used in the Ottoman palace art, it never showed itself in the folk arts of the same period. The tulip motif was experienced in the golden period in Ottoman palace art and was able to express itself partially in folk art. The star motif has had much mention of itself in folk art as well as in Ottoman palace art. Bird and tree of life motifs have survived to the present day with various applications from Ottoman palace and folk arts (F. 7).
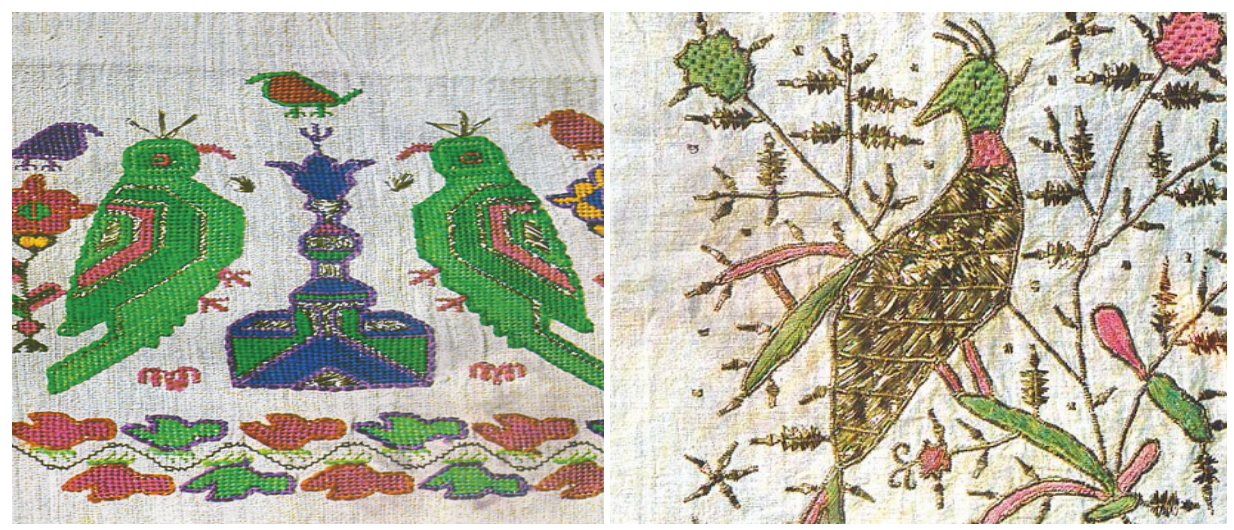

F. 7: Anatolian Folk Art "Bird Motif" (Example of Uçkur Belonging to the Bursa Region) $16^{\text {th }}$ Century Anatolian Folk Art "Bird Motif" (Example of A Bundle Belonging to the Bursa Region $)^{17}$

Anatolia is home to the oldest artistic traditions in the world. Many of these traditions have a very long history, some even as old as written history itself.

Anatolian motifs, which are part of these artistic traditions, have been used to express social status, love, expectation, belief, marriage, celibacy, migration, disaster, sadness, joy, happiness, longing, separation, wishes and many more. However, as with all works of art, several motifs have become more recognizable especially as they combine meaning with uniquely beautiful images including:

- Elibelinde

- Amulet and evil eye

- Abundance

- Ram's horn

- Tree of life 

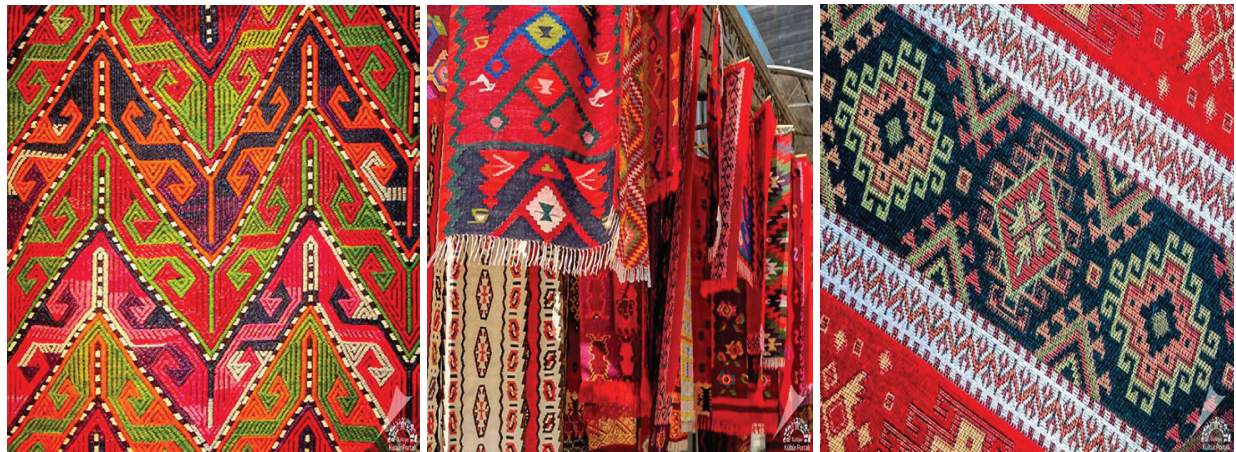

F. 8: Elibelinde-Amulet and Evil Eye-Abundance Motifs (Photos by Kaya and Romanescu, 2016)

Elibelinde motif, which symbolizes fertility, motherhood and femininity, is widely used in rugs and carpets, but it is also possible to see the motif in woven items and on sacks. In much of Anatolia, there is a belief that using motif elements in Elibelinde brings happiness to the family. As with all motifs used in Anatolia, it is possible to see designs in different ways, although the basic design is always the same in the Elibelinde motif.

The evil eye can be described as an effective force, which is believed to be present in some people, especially harmful to vulnerable and glamorous people, pets and valuable objects, resulting from a gaze. The ritual of using evil eye beads or evil eye beads for protection from negative events has emerged.

There is the same basic purpose in protecting from evil with the Amulet. The designs are not the same, but amulets are a stylized form of typical evil eye motifs. It is believed that the family will be protected from evil when these images touch rugs or other woven products in Anatolia.

In Anatolia, Abundance and happiness are considered as integral parts of a whole. The fruit and animal motifs used are thought to represent both abundance and happiness. There are abundance motif forms that express eternal happiness, such as grapes, figs, pomegranates, watermelons, melons, mulberries, fish, rams, deer, butterflies, bulls, snakes, and dragons. In addition, the lotus flower, which represents abundance and plenty, is also used. Similarly, it is believed that the motifs of trees, flowers, soil, leaves, mountains and water reflect abundance and happiness (F. 8). 

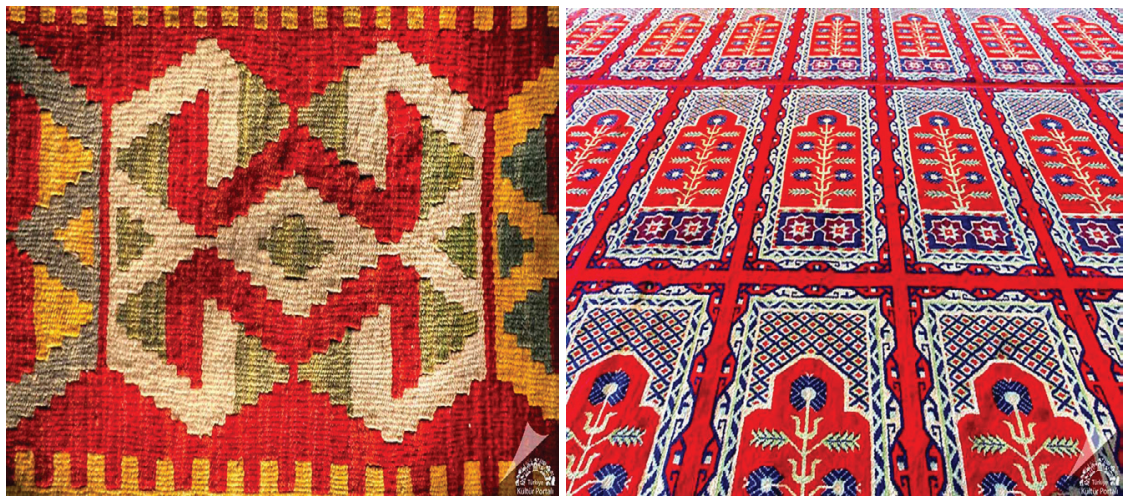

F. 9: Ram's Horn and Tree of Life Motifs (Photos by Kaya and Romanescu, 2016)

Just as the Elibelinde is a feminine symbol, the Ram's Horn is a masculine symbol. Symbolizing traditional features such as heroism and power, the Ram's Horn reflects abundance and plenty like many other traditional Anatolian motifs. It is possible to see the motif of the Ram's Horn on rugs but also on traditional tombstones. This motif is often used in the core and border sections of the weaves.

The Tree of Life motif, which symbolizes the life rising to heaven, reflects the universe that is in constant development and change. The tree of life connects to the ground with its roots descending to the depth of the ground and the underground, and the trunk with the sky and the heaven with the upper branches rising into the light. It is believed that the motif provides communication between the earth and heaven (F.9).

Besides the cypress tree, many tree symbols from fig trees to palm trees have been used for the tree of life motif. The tree of life motif is also included in works of stone, wood, pottery, tile processing, weaving, glass, illumination and miniature with various styles.
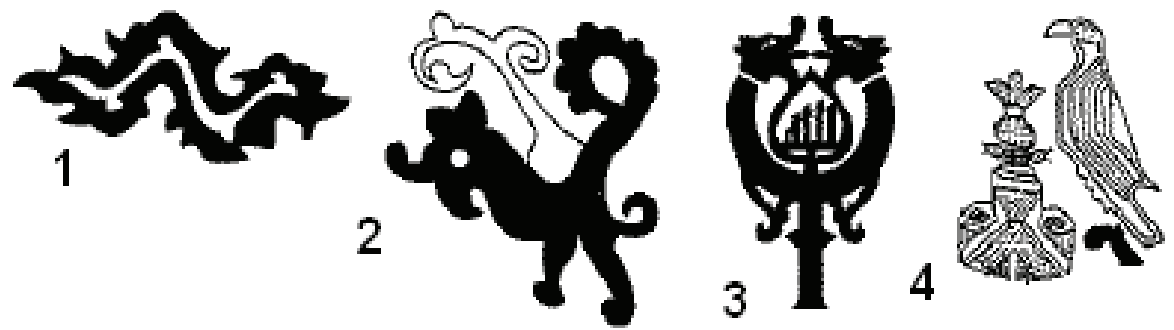

F. 10: Snake Motifs Seen in Fabrics and Embroideries. (Filiz Nurhan Ölmez, "Dokumalarda Y1lan Motifi," 17)

One of the symbols used in Anatolia is the snake motif. Symbolically, the snake shows a combination of opposing forces such as mind-emotion, love-hate, spirit-matter, life-death, good-evil, good luck-bad luck. The snake, one of the oldest gods, is 
the master of the forces of life. In Anatolia, the snake is sacred, so the snake is both feared and respected. It is believed that in some Turcoman tribes the sacred rod turned into a snake. Both the snake and its giant shape, the dragon image, are a very common symbol in ancient mythologies. ${ }^{18}$ Among the ancient Turks, the snake was a symbol of abundance, fertility, health and happiness. In some regions, it symbolizes health and strength against evil. The snake motif is a more common decoration element in plain weavings. The snake has been the symbol of the ground and underground in Central Asian Turkish belief. In Anatolia, it also symbolized evil in weaving with the influence of beliefs about the underground from past to present. The lethal and poisonous feature of the snake became an element of fear for the nomadic Turcoman living in tents and as a result of this fear protective motifs emerged. ${ }^{19}$

The snake motif has many uses (fabric, weaving, socks, rugs etc.) ${ }^{20}$ One of them is its use in fabric and embroidery. It is noteworthy that the snake motifs in the fabric and embroidery pieces are more naturalistic and in dragon form. (F. 10) When we look at the uses of snake motifs, the snakes are generally small on the products and are depicted in white on a red floor as if they were moving by curling. ${ }^{21}$

As seen in F. 11 (the first figure from the left), the use of intensive figures such as people and various animals in the tiles draws attention. It is seen that these are generally applied inside star forms. These tiles were made in turquoise, cobalt blue, purple and black as well as green, brown, yellow, and red with gold gilding as seen in the Seljuk period tiles. As stated in $\mathrm{Aker}^{22}$, these tiles are similar to Romanian tiles with their unusual star-shaped forms.

The so-called Miletus work (F. 11 right) was found in the late 14th century and is made of red cemented tiles painted with blue shades, turquoise, purple, black and green and coated with a whitish cream-colored lining under a transparent glaze. These are red-cemented ceramics that formed one of the most common groups during the Early Ottoman period.

18 Bahaeddin Ögel, Türk Mitolojisi, II. Cilt (Ankara: Türk Tarih Kurumu Yayınları, 2006), 566-567; Necati Gültepe, Türk Mitolojisi (İstanbul: Resse Yayınevi, 2014), 419-421.

19 Bahaeddin Ögel, Türk Mitolojisi, I. Cilt (Ankara: Türk Tarih Kurumu Yayınları, 2003), 490-541; Filiz Nurhan Ölmez, "Dokumalarda Y1lan Motifi," 2-21.

20 Bekir Deniz, “Anadolu - Türk Dokumalarında Ejder Motifi”, Türk Soylu Halklarının Halı Kilim ve Cicim Sanatı Uluslararası Bilgi Şöleni Bildirileri (Ankara: Atatürk Kültür Merkezi Yayını, 1996), 107-108.

21 Bekir Deniz, Türk Dünyasında Halı ve Düz Dokuma Yaygllar (Ankara: AKMB Yayınları, 2000), $192-194$.

22 Sabiha Aker, Çini Tasarımı (Ankara: Detay Yayıncılık, 2010), 30. 

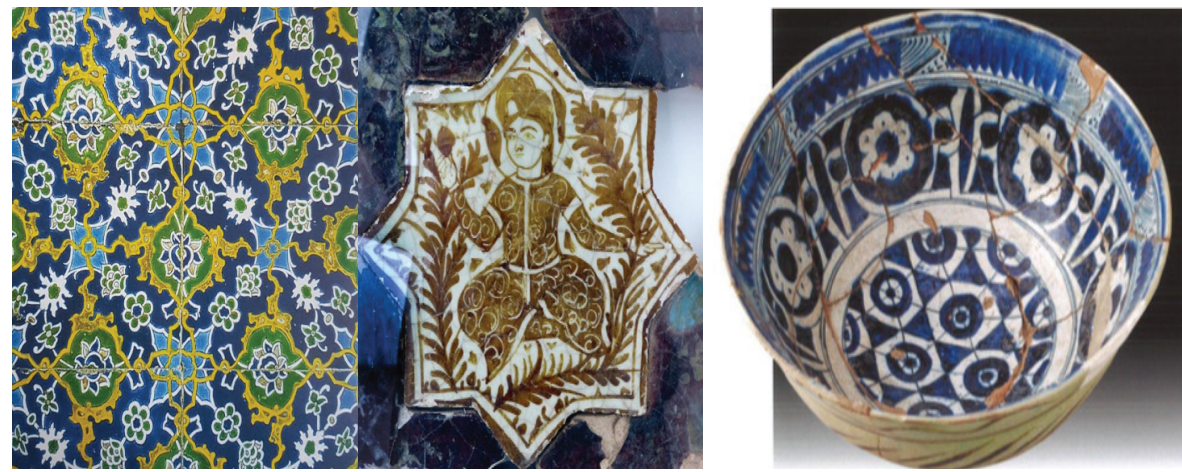

F. 11: Tile in Multicolored Glaze Technique 1465-1478 (Istanbul Topkapi Palace Supply Room) (Left); Man-Figure and Star-Shaped Tile Made with Luster Technique 1251-1252 (Konya Karatay Medresesi) (center) (http://cinili.com/archive/);

Miletus Ceramic Bowl 14-15. century (right) (Arzu Karc1, “Türk Çini Motiflerinin Çağdaş Resme Uyarlanması", 68).

It is observed that motifs such as flowers, flower rosettes, leaf, palmets, rumi, plants consisting of curled branches, stars, hexagons, rosettes, spirals, meanderings, geometric lines consisting of vertical lines, fish, bird figures, wave-rocks, and pearl sequences are used in their decorations.
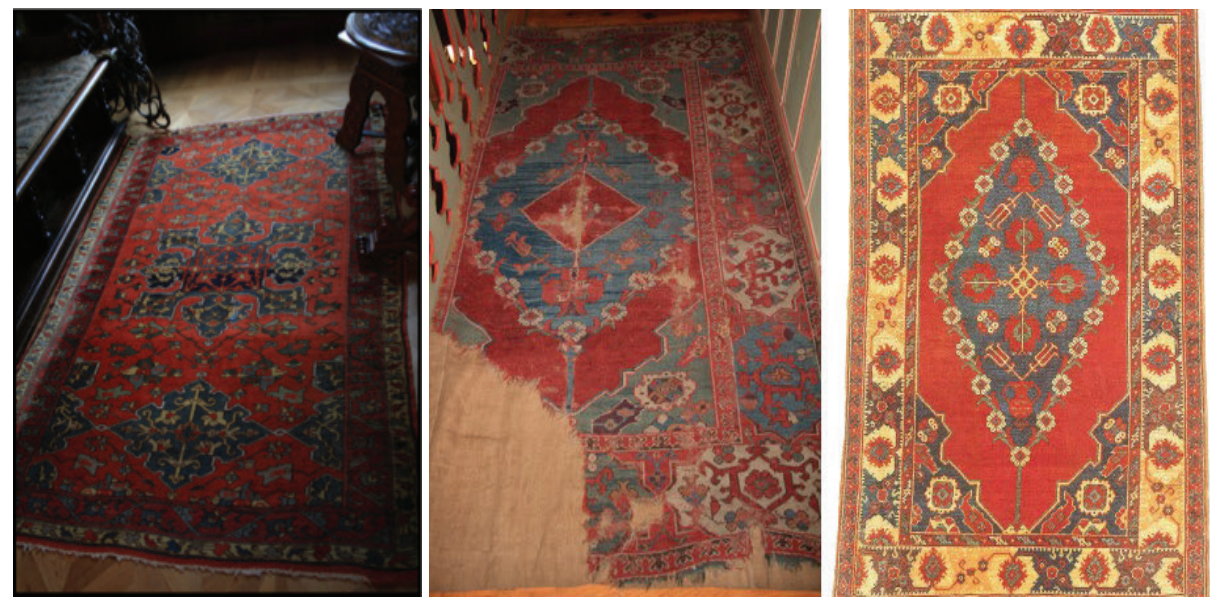

F. 12: Starry Uşak Carpet at Peleş Castle, Romania (left) (Levent Boz, "Transilvanya Bölgesi, Lutherci Mediaş Azize Margaret Kilisesindeki Anadolu Halıları”, 76.); “Transylvanian” Type Carpet

Piece with Double Mihrab with Flower Medallion at the Sinop Ethnography Museum (center); "Transylvanian" Type Carpet with Double Mihrab with Flower Medallion 290 Inventory Number in the Black Church (right) (Stefano Ionescu, Antique Ottoman Rugs in Transylvania, 131.)

In F.12., the 16-century star Uşak carpet in the inventory of Peleş Castle located in the Sinaia Region of Romania is one of the rare examples that have survived in the palaces in the region. A very small number of "Transylvanian" type carpets with double mihrabs have been identified in today's Turkish museums. The carpet with 
inventory number 242 (F.12 center), which was found at the Sinop Ethnography Museum, reflects the characteristic features of the group with its floral medallion and cartridge border and shows a great similarity with the carpet with inventory number 290 (F.12 right) located in the Black Church of Braşov (Romania).

These carpets are Turkish carpets that are woven in the main carpet centers of Western Anatolia, reaching Transylvania mainly through trade and distributed to Europe from there. The first commercial record of carpets in Transylvania is in the city of Braşov and dates back to 1462-1464 ${ }^{23}$. When the written sources were analyzed, it shows that Anatolian carpets came mainly to Transylvania through trade.

These carpets, which are present in the Protestant churches of Transylvania today, are not owned by a state institution or a central Museum in Romania, but by the church community, whose numbers are severely diminished. For this reason, every church has different approaches to protecting carpets, exhibiting them, allowing them to be touched and be photographed, sending them to exhibition, and cleaning them.

Today, it is of great importance to preserve and promote this valuable cultural treasure, which should be considered as the common cultural heritage of Romania and Turkey.

\section{Conclusion}

Culture, expressed as the common mind of a society, carries out its presentation and transmission through cultural symbols. Each culture enables the transfer and creation of different experiences and perceptions through its own cultural symbols. At this point, cultural symbols form the basis of making sense by conveying to individuals the ways of thinking, feeling, believing, etc. In other words, cultural symbols play the

role of communication tools both in the relations of individuals within a society and in their relations with other societies.

The symbolism of folk art and color of both Romania and Turkey was examined in this study as well as related to the use of different cultures and traditions, and at this point we can say that the differences show themselves in all areas. In this context, it is seen that symbols in folk art are used in many areas from textile to weaving, from ceramics to wood, especially in the cultures of these countries, and that they have different meanings in their colors.

Colors especially have been an important symbol in the cultures of societies since ancient times. Sometimes while defining directions (using black color as a symbol of north for thousands of years by Turks), sometimes expressing national feelings, while

23 Stefano Ionescu, Antique Ottoman Rugs in Transylvania, (Roma: 2007), 26. 
defining gender (blue and pink), determining religious identities (blue is accepted as a sacred color for Jews and green is for the Muslims), while mosques, churches, temples and architectural buildings were decorated, colors were used with their symbolic meanings in mind. Today, the color symbolism of the old times has left its place to functionality and gained a different dimension. The comfort, health and efficiency of individuals are now considered.

Colors are perceived and reflected differently in each culture starting from the first periods of history. In addition, it has been seen that colors have important symbolic meanings in cultures during the historical process and give direction to the lives of individuals.

In this context, in this study, color and symbolism were emphasized in the works used in many different fields in Romanian and Turkish folk art (clothing, weaving, ceramics, wood, etc.) and the colors and symbols in the folk art of the two countries were discussed with an analogical approach. With the study, it has been concluded that both countries have a distinctive folk art and that the symbols used in folk arts reflect their own culture and contain different meanings and colors have different meanings from the past to the present. At the same time, it was concluded that some symbols in Romanian and Turkish folk art were similar.

Peer-review: Externally peer-reviewed.

Conflict of Interest: The authors have no conflict of interest to declare.

Grant Support: The authors declared that this study has received no financial support.

Hakem Değerlendirmesi: Dış bağımsız.

Çıkar Çatışması: Yazarlar çıkar çatışması bildirmemiştir.

Finansal Destek: Yazarlar bu çalışma için finansal destek almadığını beyan etmiştir.

\section{References/Kaynakça}

Aker, Sabiha. Çini Tasarımı. Ankara: Detay Yayıncılık, 2010.

Anonymous. Sanat Dünyamız 15 (1979): 18-21.

Baker, L. Patricia and Hülya Tezcan. Silks for the Sultans Topkapı Sarayı. İstanbul: Ertuğ \& Kocabıyık Yayınları, 1998.

Barry, Marie Porterfield. Çinili Arşiv. Accessed 20 January 2020 http://cinili.com/archive/

Behrens, Roy R. "The Swastika: Symbol Beyond Redemption (review).” Leonardo 34-3 (2001): 280.

Boz, Levent. "Transilvanya Bölgesi, Lutherci Mediaş Azize Margaret Kilisesindeki Anadolu Halılar1.” M.A. Thesis, Hacettepe University, 2013.

Brunvand, Jan. “The Study of Romanian Folklore.” Journal of the Folklore Institute 9 2/3 (1972): 133-161. Accessed 18 December 2020. https://doi.org/10.2307/3814162

Claessens, Martine. "Romania's Secret Language." Accessed 19 December 2020. https:// martineclaessens.com/ 
Comas, David, H. Schmid, S. Braeuer, C. Flaiz, A. Busquets, F. Calafell, J. Bertranpetit, H-G. Scheil, W. Huckenbeck, L. Efremovska and H. Schmidt, "Alu Insertion Bertranpetit, Polymorphisms in the Balkans and the Origins of the Aromuns." Annals of Human Genetics 68-2 (2004): 120-127.

Coussens, Regina. "Folk Culture as Symbol in Contemporary Romania". Research Report 24: Economy, Society and Culture in Contemporary Romania 35 (1984): 129-138.

Deniz, Bekir. “Anadolu - Türk Dokumalarında Ejder Motifi”. Türk Soylu Halklarının Halı Kilim ve Cicim Sanatı Uluslararası Bilgi Şöleni Bildirileri. Ankara: Atatürk Kültür Merkezi Yayını, 1996, 107-108.

Deniz, Bekir. Türk Dünyasında Halı ve Düz Dokuma Yaygılar. Ankara: Atatürk Kültür Merkezi Yayınlar1, 2000.

Doble, Liliana, O. Stan, Marius D. Suteu, Adina Albu, G. Bohm, A. Tsatsarou-Michalaki and Eleni Gialinou. "Romanian Traditional Motif - Element of Modernity in Clothing." IOP Conference Series: Materials Science and Engineering 254 (2017): 1-5.

Gabain, Annemarie Von. "Renklerin Sembolik Anlamlar1.” Translated by Semih Tezcan, Türkoloji Dergisi 3 (1968): 107-113.

Geisler, E. Michael. Introduction: What Are the National Symbols and What Do They Do to Us? National Symbols, Fractured Identities. Hanover and London: Middlebury College Press, 2005.

Geertz, Clifford. The Interpretation of Culture. New York: Basic Books, 1973.

Ghinoiu, Ion. Mica Enciclopedie De Tradiții Romanești. București: Agora Editura, 2008.

Gültepe, Necati. Türk Mitolojisi. İstanbul: Resse Yayınevi, 2014.

Ionescu, Stefano. Antique Ottoman Rugs in Transylvania. Roma, 2007.

Karc1, Arzu. "Türk Çini Motiflerinin Çağdaş Resme Uyarlanması.” M.A. Thesis, Hacettepe University, 2018.

Kuru, Ayşin. “Geleneksel Motiflerin Kimliklerini Kaybetmeden Yeni Tasarımlara Dönüşmeleri.” Yüksek Lisans Tezi, İstanbul Mimar Sinan Güzel Sanatlar Üniversitesi, 2006.

Lizardo, Omar. “Cultural Symbols and Cultural Power.” Qualitative Sociology 39/2 (2016): 195-198.

Mocenco, Alexandra, Sabina Olaru, Georgeta Popescu and Carmen Ghituleasa. "Romanian Folklore Motifs in Fashion Design." Annals of the University of Oradea Fascicle of Textiles, Leatherwork XV (2014): 63-68.

Ögel, Bahaeddin. Türk Mitolojisi. I. Cilt. Ankara: Türk Tarih Kurumu Yayınları, 2003.

Ögel, Bahaeddin. Türk Mitolojisi. II. Cilt. Ankara: Türk Tarih Kurumu Yayınları, 2006.

Ölmez, Filiz Nurhan. “Dokumalarda Y1lan Motifi.” Süleyman Demirel Üniversitesi Güzel Sanatlar Fakültesi Hakemli Dergisi Art-E 06 (2010): 2-21.

Pop, Ion-Aurel. Identitatea Românească. Romania: Contemporanul Publishing House, 2006. Sanat Dergisi 7: Topkapı Sarayı Müzesi (Nisan 1982)

Sazak, Gözde. Türk Sembolleri Hun Dönemi Türk Motif ve Sembollerinin Sanata ve Hayata Yansıması. İstanbul: İlgi Kültür Sanat Yayınları, 2014.

Stoltenberg, Hannah. "Sacred Movement: Connecting with the Divine Kathak as Axis Mundi." Journal of Dharma Studies 1 (2019): 303-312.

Zlatev, Zlatin, Liliana Indrie, Julieta Ilieva and Teodora Ivanova. "Analysis on Colors of Folk Costume and Their Application in Contemporary Textile Design." Annals of The University of Oradea Fascicle of Textiles, Leatherwork XX (2019): 125-130. 
"Textile Fragments from Romanian Folklore". Accessed 11 January 2020 https://aleximreh.wordpress.com/2017/12/21/swastika-in-old-europe/

“Geometric Motifs from Romanian Folklore”. Accessed 09 December 2019. https://unaltfeldejurnal.files.wordpress.com/2012/06/scan10017.jpg

"The Snake Motif in Romanian Ceramic". Accessed 25 December 2019. https://www.artizanescu.ro/farfurie-romaneasca-traditionala---sarpele-casei-diam-17-5---18$\mathrm{cm} / 3772 . h t m \#$

The Line Motif in Romanian Ceramic. Accessed 25 January 2020.

https://limbaromana.org/revista/motive-geometrice/

The Circle Motif in Romanian Ceramic. Accessed 20 November 2019. https://www.invietraditia.ro/editorial/ceramica-autentica-romaneasca/ 
